\title{
Uji Tantang Bakteri Vibrio harveyi Pada Pasca Larva Udang Vaname (Litopenaeus vannamei)
}

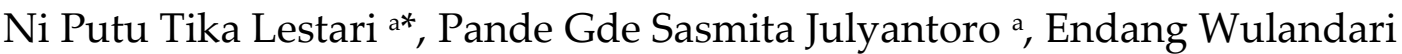 \\ Suryaningtyas a \\ a Program Studi Manajemen Sumberdaya Perairan, Fakultas Kelautan dan Perikanan, Universitas Udayana, Bukit Jimbaran, Bali-Indonesia \\ * Penulis koresponden. Tel.: +62-877-604-419-40 \\ Alamat e-mail: tikaebonk66@gmail.com
}

Diterima (received) 27 Juli 2018; disetujui (accepted) 15 Agustus 2018

\begin{abstract}
This research aims to determine the survival of Litopenaeus vannamei post larvae when challenged with various density of pathogenic Vibrio harveyi. The L. vannamei post larvae used in this study was obtained from Vannamei Broodstock Center BPIUUK, Karangasem Bali. This research was conducted for two months, from April to May 2018 in fishery laboratory, Faculty of Marine Science and Fisheries, Udayana University by using complete randomized experimental design with four different $V$. harveyi density and three times repetitions. The study showed that the higher density of pathogenic $V$. harveyi resulted on the lower survival of L. vannamei post larvae. The highest density of $V$. harveyi $10^{7} \mathrm{CFU} / \mathrm{mL}$ in treatment $\mathrm{D}$ resulted on $53 \pm 5.77 \%$ post larvae survival, while treatment $\mathrm{A}$ as control without addition of $V$. harveyi was still has survival of $100 \pm 0.00 \%$ at the end of experiment. The density $10^{5} \mathrm{CFU} / \mathrm{mL}$ of $V$. harveyi (Treatment B) seems able to be tolerated by L. vannamei post larvae since the shrimp was still have high survival at this $V$. harveyi density. Further both $V$. harveyi density of $10^{6} \mathrm{CFU} / \mathrm{mL}$ and $10^{7} \mathrm{CFU} / \mathrm{mL}$ were not able to tolerated by the shrimp post larvae and lead to the high shrimp mortality. Although affected on shrimp survival, addition of $V$. harveyi have no significant effect to the weight of shrimp post larvae between treatments.
\end{abstract}

Keywords: Litopenaeus vannamei, Vibrio harveyi, Challenged Test, Shrimp Post Larvae

\begin{abstract}
Abstrak
Penelitian ini bertujuan untuk mengetahui tingkat kelulushidupan pasca larva Udang Vaname yang diuji tantang dengan bakteri patogen Vibrio harveyi. Pasca larva Udang Vaname yang digunakan dalam penelitian ini diperoleh dari Vannamei Broodstock Center BPIUUK, Karangasem Bali. Penelitian ini dilaksanakan selama dua bulan, yaitu pada bulan April sampai dengan bulan Mei 2018 di laboratorium perikanan, Fakultas Ilmu Kelautan dan Perikanan, Universitas Udayana dengan menggunakan rancangan acak lengkap, 4 perlakuan dengan kepadatan bakteri yang berbeda dan 3 kali ulangan. Penelitian ini menunjukkan bahwa semakin tinggi kepadatan bakteri patogen $V$. harveyi yang digunakan mengakibatkan tingkat kelulushidupan pasca larva Udang Vaname menjadi rendah. Kepadatan bakteri $V$. harveyi tertinggi yaitu $10^{7} \mathrm{CFU} / \mathrm{mL}$ terdapat pada perlakuan D dengan tingkat kelulushidupan sebesar $53 \pm$ $5,77 \%$, sementara Perlakuan A sebagai kontrol yaitu tanpa penambahan bakteri $V$. harveyi, memiliki tingkat kelulushidupan sebesar $100 \pm 0,00 \%$ pada akhir percobaan. Kepadatan bakteri $V$. harveyi $10^{5} \mathrm{CFU} / \mathrm{mL}$ pada perlakuan B masih dapat ditoleransi oleh pasca larva Udang Vaname karena memiliki tingkat kelulushidupan yang tinggi. Selanjutnya pada kepadatan bakteri $V$. harveyi $10^{6} \mathrm{CFU} / \mathrm{mL}$ dan $10^{7} \mathrm{CFU} / \mathrm{mL}$ tidak dapat ditoleransi oleh pasca larva Udang Vaname karena menyebabkan kematian udang yang tinggi. Meskipun penambahan $V$. harveyi berpengaruh signifikan terhadap tingkat kelulushidupan tetapi tidak berpengaruh signifikan terhadap pertumbuhan bobot pasca larva Udang Vaname antar perlakuan.
\end{abstract}

Kata Kunci: Litopenaeus vannamei, Vibrio harveyi, Uji Tantang, Larva Udang

\section{Pendahuluan}

Udang Vaname (Litopenaeus vannamei) merupakan udang introduksi dari Hawaii dan Florida yang secara resmi ditetapkan sebagai salah satu komoditas unggulan perikanan budidaya oleh Menteri DKP pada tahun 2001 karena diminati oleh pasar dunia (Prabowo, 2003). Kelebihan Vaname diantaranya adalah pertumbuhannya cepat, nilai konversi pakan atau Feed Convertion 
Ratio (FCR) yang rendah, mampu beradaptasi terhadap kisaran salinitas yang tinggi, lebih tahan terhadap beberapa penyakit, dan sangat memungkinkan untuk dipelihara di tambak dengan kondisi padat tebar yang tinggi karena mampu memanfaatkan pakan dan ruang secara lebih efisien (Nur, 2011).

Banyaknya pembudidaya yang melakukan budidaya Udang Vaname di Indonesia mengakibatkan kebutuhan benih Udang Vaname juga ikut meningkat. Hal ini mendorong pemerintah untuk dapat memenuhi kebutuhan benih Udang Vaname melalui peningkatan kegiatan pembenihan di instansi pemerintahan terkait. Salah satu instansi pemerintahan yang memproduksi benih Udang Vaname di Indonesia adalah Balai Produksi Induk Udang Unggul dan Kekerangan (BPIUUK) Karangasem, Bali. BPIUUK Karangasem merupakan pusat penghasil induk dan benih Udang Vaname (Broodstock Center).

Masalah yang sering terjadi dalam produksi dan pemuliaan Udang Vaname adalah timbulnya penyakit, terutama yang disebabkan oleh bakteri. Salah satu penyakit bakterial yang banyak menyerang larva udang adalah penyakit vibriosis yang disebabkan oleh bakteri Vibrio harveyi. Serangan penyakit ini dapat menimbulkan mortalitas tinggi pada pembenihan udang (LavillaPittogo et al., 1990). Biasanya stadia yang diserang mulai dari stadia zoea sampai awal pasca larva (Mariyono et al., 2006). Salah satu kegiatan yang dilakukan untuk mengetahui kualitas benur udang adalah dengan melakukan uji tantang. Uji tantang pada benur udang dilakukan untuk melihat bagaimana respon benur terhadap penambahan bakteri Vibrio harveyi sebagai dasar untuk mengetahui kualitas benur yang nantinya akan menjadi calon induk.

\section{Metode Penelitian}

\subsection{Waktu dan Lokasi Penelitian}

Penelitian ini dilaksanakan selama 2 bulan yaitu pada bulan April-Mei 2018 di Laboratorium Ilmu Perikanan Universitas Udayana. Pasca larva Udang Vaname yang akan dijadikan sebagai sampel uji, diambil langsung dari Balai Produksi Induk Udang Unggul dan Kekerangan Karangasem, Bali (BPIUUK).

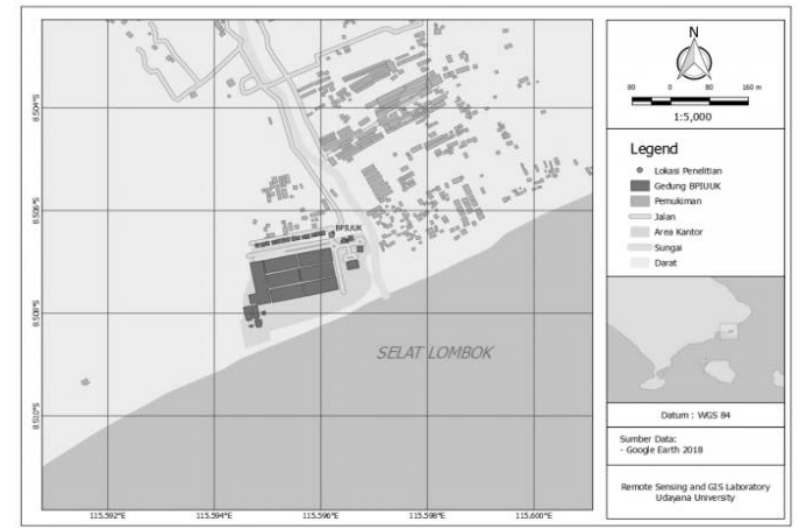

Gambar 1. Lokasi Penelitian

\subsection{Alat dan Bahan}

Alat yang digunakan dalam penelitian ini diantaranya beaker glass, erlenmeyer $250 \mathrm{~mL}$, cawan petri, autoklaf (Hirayama, HL-36Ae), toples, nampan, selang aerasi, gelas ukur, kapas, tabung reaksi, hot plate stirrer (Thermo Scientific), aluminium foil, $\mathrm{pH}$ meter (Lutron, $\mathrm{PH}-222)$ penggaris, refraktometer (Refractometer Atago), inkubator, aerator, heater, mikropipet (Mikropipette Socoret), mikro tip, gloves, aquarium, spektrofotometer (Genesys 10s UV-Vis USA), dan timbangan digital (Kern, WL-100110). Sedangkan bahan yang digunakan diantaranya pasca larva Udang Vaname PL-10, aquades, 8,91 gram media TCBS (Thiosulphate Citrate Bile Salt), 2 gram media LB (Luria Bertani Broth), air laut, alkohol 70\%, 35 gram $\mathrm{NaCl}$, pakan udang, dan bakteri Vibrio harveyi.

\subsection{Metode Penelitian}

Penelitian yang dilakukan bersifat eksperimental menggunakan Rancangan Acak Lengkap (RAL) dengan 4 perlakuan dengan konsentrasi berbeda dan 3 kali ulangan, sehingga terdapat 12 unit percobaan. Hewan uji yang digunakan dalam penelitian ini adalah pasca larva Udang Vaname hasil pemuliaan (PL-10) yang diambil dari BPIUUK Karangasem, Bali. Pada penelitian ini, pasca larva Udang Vaname akan diuji tantang dengan bakteri Vibrio harveyi menggunakan metode perendaman untuk mengetahui ketahanan dan kelulushidupannya. Konsentrasi yang digunakan adalah perlakuan A kontrol, perlakuan $B$ dengan konsentrasi Vibrio harveyi $10^{5} \mathrm{CFU} / \mathrm{mL}$, perlakuan $C$ dengan konsentrasi Vibrio harveyi $10^{6}$ $\mathrm{CFU} / \mathrm{mL}$, dan perlakuan $\mathrm{D}$ dengan konsentrasi Vibrio harveyi $10^{7} \mathrm{CFU} / \mathrm{mL}$. 


\subsubsection{Pembuatan Media Dan Kultur Bakteri}

Sebelum kegiatan penelitian, dilakukan sterilisasi peralatan. Sterilisasi dilakukan untuk mematikan segala bentuk kehidupan mikroorganisme dalam peralatan penelitian agar tidak terjadi kontaminasi. Dalam penelitian ini proses sterilisasi dilakukan dengan 2 cara yaitu menggunakan autoklaf dan bunsen.

Strain bakteri yang digunakan dalam penelitian ini adalah bakteri pathogen yang merupakan koleksi dari Laboratorium Ilmu Perikanan Fakultas Kelautan dan Perikanan Udayana. Strain bakteri terlebih dahulu diinokulasi kedalam media LB Broth. Selanjutnya isolat bakteri diambil secara aseptik dengan menggunakan mikropipet sebanyak 0,1 mL lalu disebar diatas media TCBS dengan metode spreadplate (Pelczar dan Chan, 2002). Setelah ditumbuhkan, bakteri selanjutnya diinkubasi selama 24 jam pada suhu 37॰C (Chau et al., 2011). Bakteri yang telah tumbuh pada media TCBS kemudian dikultur kembali ke dalam media LB Broth. Untuk mengetahui kepadatan bakteri dilakukan dengan menggunakan spektrofotometer pada panjang gelombang $550 \mathrm{~nm}$ (Bibiana, 1994).

\subsubsection{Persiapan Organisme Uji}

Pasca larva yang digunakan dalam penelitian ini sebelumnya sudah melewati treatmen probiotik mulai dari stadia naupli sampai pasca larva. Pasca larva diadaptasi selama 1 malam sebelum diinfeksi bakteri dengan metode perendaman. Wadah yang digunakan sebagai media pemeliharaan adalah toples yang berkapasitas $500 \mathrm{~mL}$ dengan padat penebaran 10 ekor per toples. Penelitian ini menggunakan sistem Waterbath, dimana toples sebagai media pemeliharaan diletakkan di dalam akuarium yang telah berisi air dan heater. Setiap akuarium berisikan 6 buah toples dan 1 heater dengan suhu $28^{\circ} \mathrm{C}$ serta penambahan air diluar toples sebanyak 6-7 Liter. Sistem ini dilakukan untuk menjaga suhu tetap stabil dalam toples. Selama penelitian berlangsung, pasca larva diberikan pakan berupa fine crumble. Frekuensi pemberian pakan 5 kali per hari yaitu pukul 07.00; 11.00; 15.00; 18.00; dan 22.00 WITA (Nurdjana et al., 1989 dalam Bakhtiar, 2004).

\subsubsection{Uji Tantang}

Setiap unit perlakuan diinfeksi oleh bakteri Vibrio harveyi dengan konsentrasi berbeda. Selama uji tantang, pasca larva diberi pakan dan aerasi. Pengamatan dimulai jam 07.00 WITA pasca infeksi dengan mengamati tingkat kelulushidupan dan abnormalitas yang terjadi pada pasca larva setiap 6 jam sekali. Pengamatan dihentikan jika mortalitas pasca larva Udang Vaname sudah mencapai 50\% $\left(\mathrm{LD}^{50}\right)$. Tingkat kelulushidupan pasca larva udang dihitung pada akhir penelitian menurut Effendi (1997). Setelah penelitian selesai, bakteri pada media pemeliharaan dan larva dihitung dengan menggunakan metode perhitungan TPC (Total Plate Count) dengan jumlah koloni harus berkisar 30-300 (Hadioetomo, 1993).

\subsection{Analisis Data}

Data yang diperoleh selama penelitian ini dianalisis menggunakan bantuan software Microsoft Excel 2010 dan dengan analisis statistik menggunakan software SPSS (Statistical Product and Service Solutions). Analisis yang dilakukan meliputi Analisis Ragam (ANOVA) one way untuk mengetahui pengaruh perlakuan terhadap parameter. One way anova dilakukan untuk mengetahui ada atau tidaknya perbedaan rata-rata untuk lebih dari dua kelompok sampel yang tidak berhubungan. Selanjutnya dilakukan Uji tukey apabila perlakuan yang diberikan memberi pengaruh nyata atau tidak. Data yang diperoleh disajikan dalam bentuk tabel dan grafik.

\subsubsection{Tingkat Kelulushidupan}

Tingkat kelulushidupan merupakan perbandingan jumlah udang pada akhir dan awal penelitian. Tingkat kelulushidupan udang dihitung dengan menggunakan rumus (Effendi, 1997) yaitu:

$S R=\frac{N_{t}}{N_{o}} \times 100 \%$

dimana $S R$ adalah tingkat kelulushidupan (\%), $N_{t}$ adalah jumlah udang pada akhir penelitian (ekor), dan $N_{o}$ adalah Jumlah udang pada awal penelitian (ekor). Tingkat kelulushidupan yang didapatkan kemudian dimasukkan dalam kriteria tingkat kelulushidupan menurut Effendi, 1997.

\subsubsection{Pertumbuhan Panjang Mutlak}

Pertumbuhan panjang udang dihitung dengan menggunakan rumus pertumbuhan panjang 
mutlak (Growth Rate) sebagai berikut (Effendi, 1998):

$L_{m}=L_{t}-L_{o}$

dimana $L_{m}$ adalah pertumbuhan panjang mutlak $(\mathrm{cm}), L_{t}$ adalah panjang rata-rata akhir udang $(\mathrm{cm})$, dan $L_{o}$ adalah panjang rata-rata awal udang $(\mathrm{cm})$. Pertumbuhan panjang mutlak yang didapatkan kemudian dimasukkan dalam kriteria pertumbuhan panjang mutlak menurut Effendi, 1998.

\subsubsection{Pertumbuhan Bobot Mutlak}

Pertumbuhan bobot udang dihitung dengan menggunakan rumus pertumbuhan bobot mutlak (Growth Rate) sebagai berikut (Effendi, 1998):

$W_{m}=W_{t}-W_{o}$

dimana $W_{m}$ adalah pertumbuhan bobot mutlak (g), $W_{t}$ adalah bobot rata-rata akhir udang $(\mathrm{g})$, dan $W_{o}$ adalah bobot rata-rata awal udang (g). Pertumbuhan bobot mutlak yang didapatkan kemudian dimasukkan dalam kriteria pertumbuhan bobot mutlak menurut Effendi, 1998.

\subsubsection{Kelimpahan Total Bakteri Vibrio harveyi}

Kelimpahan total bakteri pada media pemeliharaan dan larva dihitung menggunakan metode hitungan cawan sebar dengan perhitungan sebagai berikut (Hadioetomo, 1993):

$\sum$ Bakteri $=N \times \frac{1}{f} \times \frac{1}{\sum \text { Penebaran }}$

dimana EBakteri adalah banyaknya sel bakteri $(\mathrm{CFU} / \mathrm{mL}), N$ adalah jumlah koloni bakteri, $f$ adalah faktor pengenceran, dan $\sum$ Penebaran adalah jumlah sampel yang ditebar pada media kultur (mL). Kelimpahan total bakteri yang didapatkan kemudian dimasukkan dalam kriteria kelimpahan total bakteri menurut Hadioetomo, 1993.

\section{Hasil dan Pembahasan}

3.1 Pengaruh Kuantitas Bakteri Vibrio harveyi Terhadap Tingkat Kelulushidupan Pasca Larva Udang Vaname

Selama uji tantang diperoleh rata-rata tingkat kelulushidupan terendah pada perlakuan D (Vibrio harveyi $10^{7} \mathrm{CFU} / \mathrm{mL}$ ) yaitu sebesar $53 \pm 5,77 \%$ dan nilai rata-rata tertinggi pada perlakuan A (kontrol) yaitu sebesar 100 $\pm 0,00 \%$ (Gambar 2). Analisis menggunakan ANOVA untuk menguji perlakuan terhadap tingkat kelulushidupan pasca larva Udang Vaname diperoleh hasil yang signifikan $(\mathrm{p}<0,05)$, dimana hasil tersebut menunjukkan bahwa perlakuan memberikan pengaruh yang berbeda nyata.

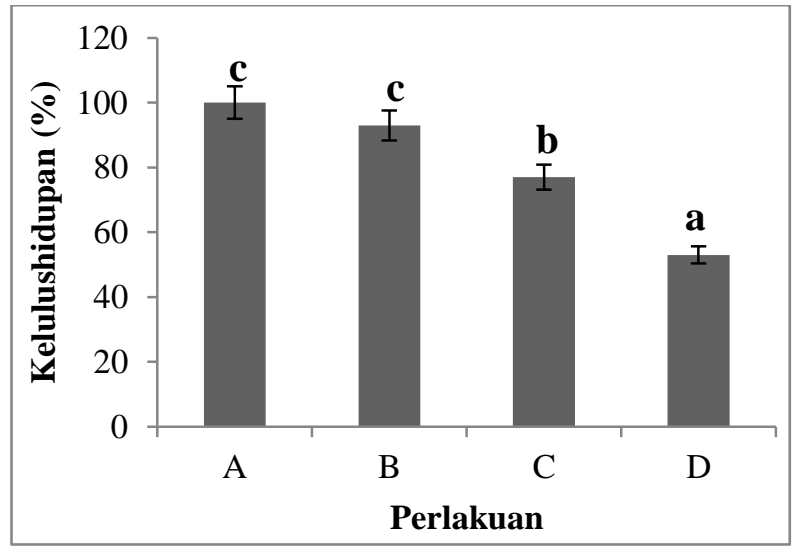

Gambar 2. Tingkat Kelulushidupan Pasca Larva Udang Vaname.

Hasil penelitian menunjukkan bahwa bakteri Vibrio harveyi dapat menginfeksi pasca larva Udang Vaname dengan mortalitas 50\% (LD ${ }^{50}$ ) dalam jangka waktu 4 hari (96 jam) perendaman. Tingkat kelulushidupan terendah terdapat pada perlakuan D (Vibrio harveyi $10^{7} \mathrm{CFU} / \mathrm{mL}$ ) yaitu sebesar $53 \pm 5,77 \%$. Kematian pasca larva pada perlakuan D (Vibrio harveyi $10^{7} \mathrm{CFU} / \mathrm{mL}$ ) mulai terjadi pada 6 jam pasca infeksi bakteri. Setelah pemberian konsentrasi bakteri, pola pergerakannya tidak beraturan berakhir dengan diam di dasar wadah dan tidak responsif terhadap pakan. Hal ini diduga karena tingginya konsentrasi bakteri Vibrio harveyi menyebabkan stress sehingga terjadi gejala yang tidak normal pada udang. Pasca larva Udang Vaname hasil pemuliaan yang mati pada perlakuan ini membuktikan bahwa dengan kepadatan bakteri Vibrio harveyi $10^{7} \mathrm{CFU} / \mathrm{mL}$ pasca larva sudah tidak bisa beradaptasi dengan baik dan dapat menyebabkan kematian secara massal selama pemeliharaan. Mariyono et al. (2006) mengemukakan bahwa konsentrasi bakteri Vibrio harveyi $10^{7} \mathrm{CFU} / \mathrm{mL}$ dapat menyebabkan kematian sebesar $100 \%$ dalam uji terhadap tingkat mortalitas udang. Hasil ini didukung oleh penelitian Feliatra et al. (2014) dengan menggunakan pasca larva udang (windu) hasil produksi BBPBAP Jepara yang diuji patogen dengan metode perendaman selama 96 jam menggunakan bakteri Vibrio harveyi 
mengakibatkan kematian benur sebesar 36,7\% pada konsentrasi $10^{5} \mathrm{CFU} / \mathrm{mL}, 73,3 \%$ pada konsentrasi $10^{6} \mathrm{CFU} / \mathrm{mL}, 100 \%$ pada konsentrasi $10^{7} \mathrm{CFU} / \mathrm{mL}$, dan tidak terdapat kematian pada perlakuan kontrol. Pernyataan tersebut mengindikasikan bahwa konsentrasi bakteri yang ditambahkan berbanding lurus dengan kematian pasca larva Udang Vaname, dimana semakin tinggi konsentrasi bakteri yang ditambahkan menyebabkan tingkat kelulushidupan semakin menurun.

Tingkat kelulushidupan pada perlakuan $\mathrm{C}$ (Vibrio harveyi $10^{6} \mathrm{CFU} / \mathrm{mL}$ ) yaitu sebesar $77 \pm 5,77 \%$. Kematian pasca larva mulai terjadi pada 6 jam pasca infeksi bakteri. Selama perlakuan terlihat jelas bahwa pasca larva Udang Vaname berenang tanpa arah, sering mendekati sumber aerasi, dan melemah di dasar wadah serta kurang respontif terhadap pakan, hal ini menandakan bahwa penambahan konsentrasi bakteri Vibrio harveyi mulai berpengaruh terhadap kondisi tubuh pasca larva Udang Vaname. Penelitian yang telah dilakukan oleh Feliatra et al. (2014) menunjukkan bahwa tingkat kelulushidupan pasca larva udang (windu) dengan penambahan konsentrasi bakteri $10^{6} \mathrm{CFU} / \mathrm{mL}$ didapatkan hasil sebesar 26,7\% dengan waktu perendaman yang sama.

Tingkat kelulushidupan pada perlakuan B (Vibrio harveyi $10^{5} \mathrm{CFU} / \mathrm{mL}$ ) yaitu sebesar $93 \pm 5,77 \%$. Kematian pasca larva mulai terjadi pada 60 jam pasca infeksi bakteri. Keadaan pasca larva menunjukkan kurang responsif terhadap pakan dan juga berenang tanpa arah. Kematian yang terjadi pada pemberian konsentrasi bakteri Vibrio harveyi $10^{5} \mathrm{CFU} / \mathrm{mL}$ ini tidak menyebabkan kematian masal dan masih mampu ditoleransi oleh pasca larva. Hoa et al. (2006) menyatakan bahwa beberapa isolat bakteri akan bersifat patogen terhadap udang pada konsentrasi $10^{5}-10^{7}$ $\mathrm{CFU} / \mathrm{mL}$ dan akan mempengaruhi sintasan larva setelah 24-48 jam. Jika dilihat dari tingkat kelulushidupan, pasca larva udang Udang Vaname hasil pemuliaan BPIUUK memperlihatkan performa yang cukup baik dari segi ketahanan tubuh terhadap infeksi Vibrio harveyi dengan konsentrasi $10^{5} \mathrm{CFU} / \mathrm{mL}$ selama 96 jam, dengan tingkat kelulushidupan yang cukup tinggi sebesar 93\%.

Tingkat kelulushidupan tertinggi terdapat pada perlakuan A (kontrol) yaitu sebesar $100 \pm 0,00 \%$. Selama penelitian pada perlakuan ini tidak terjadi kematian pada pasca larva Udang
Vaname. Hal ini diduga karena tidak terjadi perubahan kualitas lingkungan selama penelitian dan pasca larva tidak mengalami stress. Feliatra et al. (2011) mengemukakan bahwa lingkungan yang baik akan meningkatkan daya tahan organisme yang dipelihara, sedangkan lingkungan yang kurang baik akan menyebabkan organisme yang dipelihara menjadi stress dan dapat menurunkan daya tahan terhadap serangan penyakit. Selama pengamatan, respon pasca larva Udang Vaname sangat responsif terhadapt pakan dan juga berenang dengan normal sehingga kondisi seperti ini sangat mampu ditoleransi dengan baik oleh pasca larva Udang Vaname.

\subsection{Pengaruh Kuantitas Bakteri Vibrio harveyi Terhadap Intensitas Infeksi}

Hasil perhitungan kelimpahan bakteri Vibrio harveyi pada tubuh dan air media pemeliharaan pasca larva Udang Vaname diperoleh hasil yang signifikan $(\mathrm{p}<0,05)$, dimana hasil tersebut menunjukkan bahwa perlakuan berpengaruh nyata terhadap kelimpahan bakteri pada tubuh dan air media pasca larva Udang Vaname. Kelimpahan bakteri tertinggi sama-sama berada pada perlakuan D (Vibrio harveyi $10^{7} \mathrm{CFU} / \mathrm{mL}$ ) dan kelimpahan terendah terdapat pada perlakuan A (kontrol) (Gambar 3).

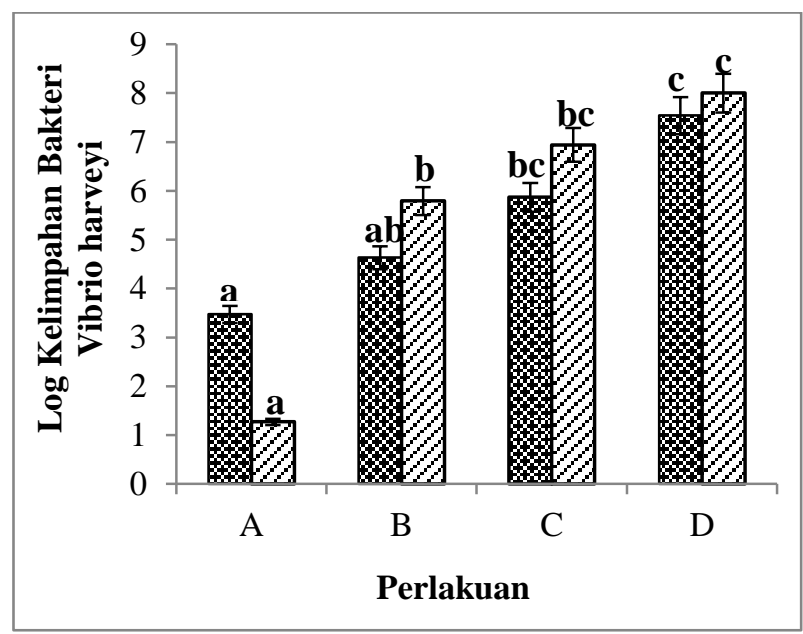

Gambar 3. Kelimpahan bakteri Vibrio pada tubuh (*) dan air media pemeliharaan $(\square)$ pasca larva Udang Vaname.

Hasil penelitian menunjukkan bahwa kelimpahan bakteri Vibrio harveyi tertinggi dalam tubuh pasca larva udang terdapat pada perlakuan D (Vibrio harveyi $10^{7} \mathrm{CFU} / \mathrm{mL}$ ) yaitu sebesar $5,4 \mathrm{x}$ $10^{7} \mathrm{CFU} / \mathrm{mL}$ dan jumlah terendah terdapat pada 
perlakuan A (kontrol) yaitu sebesar 4,7 x $10^{3}$ $\mathrm{CFU} / \mathrm{mL}$. Pada perlakuan B (Vibrio harveyi $10^{5}$ CFU/mL) kelimpahan bakteri sebesar 6,3 x $10^{4}$ $\mathrm{CFU} / \mathrm{mL}$ dan pada perlakuan C (Vibrio harveyi $10^{6}$ CFU/mL) kelimpahan bakteri sebesar 8,7 x $10^{5}$ CFU/mL. Kelimpahan bakteri menunjukkan peningkatan disetiap perlakuan dan berdasarkan analisis menggunakan ANOVA menunjukkan hasil yang signifikan. Hal ini mengindikasikan bahwa penambahan bakteri Vibrio harveyi memberikan pengaruh yang berdeda nyata pada kelimpahan bakteri dalam tubuh pasca larva Udang Vaname. Bakteri Vibrio harveyi diduga menginfeksi pasca larva udang Vaname dengan cara menempel pada eksoskeleton dan mengeluarkan bahan atau senyawa yang mendukung virulensinya.

Menurut Donnenberg (2000), mekanisme infeksi bakteri patogen dimulai dengan (i) masuknya patogen; (ii) pembentukan dan multiplikasi, dengan demikian menghindari pertahanan inang dan menyebabkan kerusakan pada jaringan dan sel; dan (iii) keluar. Mekanisme infeksi melibatkan faktor virulensi, yaitu motilitas, adhesi, invasi, degradasi jaringan inang, perolehan zat besi dan perlindungan dari pertahanan inang. Sistem pertahanan tubuh udang tidak mempunyai kemampuan mengingat antigen dan merupakan sistem kekebalan non-spesifik tetapi kekebalan ini dapat dirangsang dengan penggunaan probiotik dan immunostimulan secara optimal (Nakayama et al., 2007).

Hasil penelitian menunjukkan bahwa kelimpahan bakteri Vibrio harveyi tertinggi dalam air media pemeliharaan terdapat pada perlakuan $\mathrm{D}$ (Vibrio harveyi $10^{5} \mathrm{CFU} / \mathrm{mL}$ ) yaitu sebesar $1,0 \mathrm{x}$ $10^{8} \mathrm{CFU} / \mathrm{mL}$ dan kelimpahan terendah terdapat pada perlakuan A (kontrol) yaitu sebesar 2,7 x $10^{1}$ $\mathrm{CFU} / \mathrm{mL}$. Pada perlakuan B (Vibrio harveyi $10^{5}$ CFU/mL) kelimpahan bakteri sebesar 7,9 × $10^{5}$ $\mathrm{CFU} / \mathrm{mL}$ dan pada perlakuan C (Vibrio harveyi $10^{6}$ CFU/mL) kelimpahan bakteri sebesar 9,4 x $10^{6}$ CFU/mL. Kelimpahan bakteri menunjukkan peningkatan di setiap perlakuan dan berdasarkan analisis menggunakan ANOVA menunjukkan hasil yang signifikan. Hal ini mengindikasikan bahwa penambahan bakteri Vibrio harveyi pada pasca larva Udang Vaname memberikan pengaruh yang berdeda nyata pada kelimpahan bakteri Vibrio dalam air media.

Hasil yang didapatkan menunjukkan kelimpahan bakteri pada air media lebih tinggi dibandingkan kelimpahan pada tubuh pasca larva Udang Vaname. Hal ini diduga karena kondisi lingkungan sangat mendukung pertumbuhan bakteri, dengan memanfaatkan sisa-sisa pakan dan parameter kualitas air yang mendukung kehidupannya. Menurut Holt dan Krieg (1984), bakteri Vibrio harveyi tumbuh secara optimal pada suhu $30^{\circ} \mathrm{C}$, salinitas antara 20-30 ppt dengan $\mathrm{pH}$ 7,0 dan bersifat anaerobik fakultatif, yaitu dapat hidup baik dengan atau tanpa adanya oksigen.

Meningkatnya kelimpahan bakteri pada air media diduga karena bakteri masih dalam fase pertumbuhan (fase lag). Banyaknya sisa pakan menyebabkan tingginya kandungan nutrien dalam air, keadaan ini dimanfaatkan dengan baik oleh bakteri untuk memperbanyak diri, selain itu penelitian ini berlangsung dalam waktu singkat sehingga kelimpahan bakteri menjadi tinggi. Hal ini didukung oleh pernyataan Sugama (2006) yang menyatakan bahwa kelebihan sisa pakan di perairan dapat menyebabkan bakteri tumbuh dengan subur dan melimpah.

\subsection{Pengaruh Kuantitas Bakteri Vibrio harveyi} Terhadap Pertumbuhan Pasca Larva Udang Vaname

Hasil penelitian menunjukkan bahwa pertumbuhan rata-rata panjang mutlak pasca larva Udang Vaname terendah terdapat pada perlakuan $\mathrm{D}$ (Vibrio harveyi $10^{7} \mathrm{CFU} / \mathrm{mL}$ ) yaitu sebesar $0,52 \pm 0,07 \mathrm{~cm}$ dan pertumbuhan tertinggi terdapat pada perlakuan A (kontrol) yaitu sebesar 0,52 $\pm 0,14$ $\mathrm{cm}$. Pada perlakuan B (Vibrio harveyi $10^{5} \mathrm{CFU} / \mathrm{mL}$ ) pertumbuhan rata-rata panjang mutlak sebesar 0,39 $\pm 0,14 \mathrm{~cm}$ dan pada perlakuan C (Vibrio harveyi $10^{6} \mathrm{CFU} / \mathrm{mL}$ ) sebesar 0,29 $\pm 0,10 \mathrm{~cm}$ (Gambar 4).

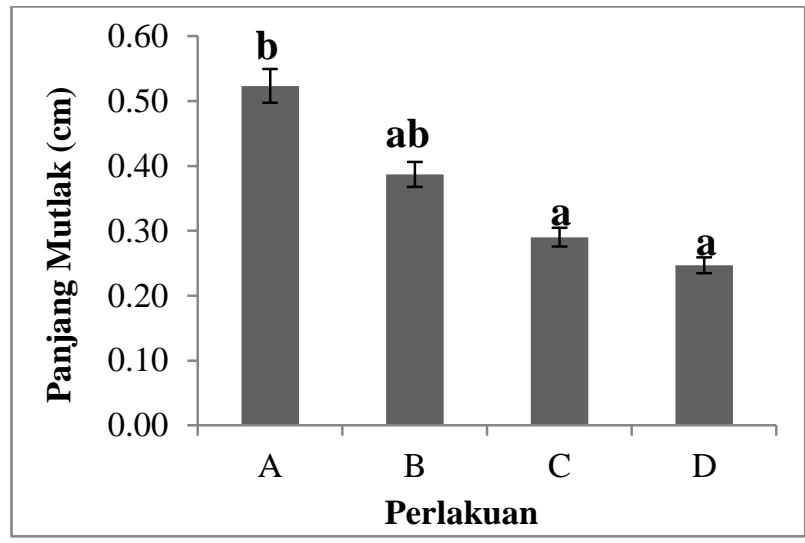

Gambar 4. Pertumbuhan Panjang Mutlak Pasca Larva Udang Vaname. 
Analisis menggunakan ANOVA untuk menguji perlakuan terhadap pertumbuhan panjang mutlak pasca larva Udang Vaname diperoleh hasil yang signifikan $(p>0,05)$, dimana hasil tersebut menunjukkan bahwa perlakuan memberikan pengaruh yang perbedaan nyata pada pertumbuhan panjang mutlak. Rendahnya nilai pertumbuhan panjang mutlak pada perlakuan D diduga disebabkan karena jumlah konsentrasi bakteri Vibrio harveyi yang diaplikasikan lebih banyak dari perlakuan lainnya. Konsentrasi bakteri yang tinggi diduga menyebabkan stress pada pasca larva sehingga mengganggu proses konsumsi dan penyerapan nutrisi yang berasal dari pakan. Brunt dan Austin (2005) serta Sheehan et al. (2009) menyatakan bahwa salah satu gejala klinis infeksi bakteri adalah respons terhadap pakan yang buruk. Keberadaan bakteri patogen dalam saluran pencernaan dapat mengganggu keseimbangan mikroba sehingga menurunkan tingkat penyerapan pakan serta meningkatkan jumlah patogen dalam saluran pencernaan (Praditia, 2009).

Hasil penelitian menunjukkan bahwa pertumbuhan rata-rata bobot mutlak pasca larva Udang Vaname terendah terdapat pada perlakuan D (Vibrio harveyi $10^{7} \mathrm{CFU} / \mathrm{mL}$ ) yaitu sebesar 0,0139 $\pm 0,00$ gram dan pertumbuhan tertinggi terdapat pada perlakuan A (kontrol) yaitu sebesar 0,0139 $\pm 0,00$ gram. Pada perlakuan B (Vibrio harveyi $10^{5} \mathrm{CFU} / \mathrm{mL}$ ) pertumbuhan rata-rata bobot mutlak sebesar 0,0126 $\pm 0,00$ gram dan pada perlakuan $C$ (Vibrio harveyi $10^{6} \mathrm{CFU} / \mathrm{mL}$ ) sebesar $0,0100 \pm 0,00$ gram (Gambar 5).

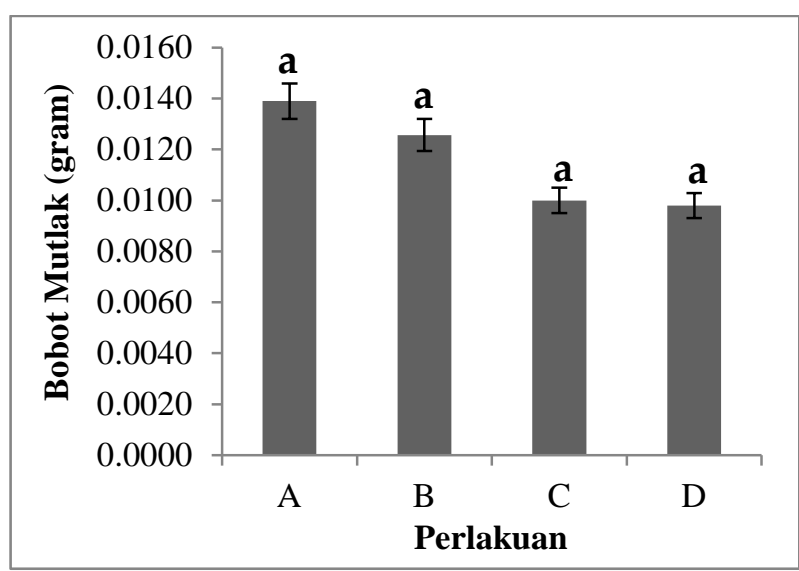

Gambar 5. Pertumbuhan Bobot Mutlak Pasca Larva Udang Vaname.

Analisis menggunakan ANOVA untuk menguji perlakuan terhadap pertumbuhan bobot pasca larva Udang Vaname diperoleh hasil yang tidak signifikan $(p>0,05)$, dimana hasil tersebut menunjukkan bahwa tidak adanya perbedaan yang nyata pada setiap perlakuan. Hal ini mengindikasikan bahwa penambahan bakteri Vibrio harveyi pada pasca larva Udang Vaname tidak mempengaruhi pertumbuhan bobotnya.

\subsection{Kualitas Air Media Pemeliharaan Pasca Penambahan Bakteri Vibrio harveyi}

Pengukuran parameter kualitas air untuk memonitoring kualitas air selama penelitian agar tetap terkontrol dan untuk memastikan bahwa pasca larva Udang Vaname tidak mengalami kematian akibat lingkungan atau kualitas air yang buruk. Hasil kualitas air yang didapatkan sesuai dengan PERMEN-KP No. 75 (2016) yang menyatakan bahwa untuk kegiatan pemeliharaan Udang Vaname parameter kualitas air suhu adalah 28-32 ${ }^{\circ} \mathrm{C}$, salinitas adalah $26-35 \mathrm{ppt}$, $\mathrm{pH}$ adalah 7-8,5, dan oksigen terlarut (DO) adalah $\geq 4 \mathrm{mg} / \mathrm{L}$ (Tabel $1)$.

Tabel 1. Parameter kualitas air media pemeliharaan pasca larva Udang Vaname selama penelitian.

\begin{tabular}{lccccccc}
\hline \multirow{2}{*}{ Perlakuan } & \multicolumn{2}{c}{ Suhu $\left({ }^{\circ} \mathbf{C}\right)$} & \multicolumn{2}{c}{ Salinitas (ppt) } & \multicolumn{2}{c}{ pH } & DO \\
\cline { 2 - 6 } & Awal & Akhir & Awal & Akhir & Awal & Akhir & (mg/L \\
\hline A (Kontrol) & 30,5 & 30,5 & 32,7 & 33,3 & 7,01 & 7,01 & $\geq 4$ \\
\hline B $\left(10^{5}\right)$ & 30,1 & 30,4 & 33 & 33,7 & 7,02 & 7,01 & $\geq 4$ \\
\hline $\left.\mathrm{C} 10^{6}\right)$ & 30,9 & 31 & 33 & 35,7 & 7,02 & 7,02 & $\geq 4$ \\
\hline D $\left(10^{7}\right)$ & 30,8 & 30,4 & 33,3 & 34,7 & 7,01 & 7,03 & $\geq 4$ \\
\hline
\end{tabular}

Data parameter kualitas air yang didapatkan selama penelitian berlangsung berada pada kisaran optimal bagi pasca larva Udang Vaname, sehingga secara keseluruhan tidak berpengaruh terhadap kematian pasca larva. Jadi, kematian pasca larva udang Vaname selama penelitian berlangsung disebabkan karena penambahan bakteri Vibrio harveyi dengan konsentrasi yang berbeda pada setiap perlakuan.

\section{Simpulan}

Tingkat kelulushidupan pasca larva Udang Vaname hasil pemuliaan BPIUUK Karangasem terendah terdapat pada perlakuan D (Vibrio harveyi $10^{7} \mathrm{CFU} / \mathrm{mL}$ ) sebesar $53 \pm 5,77 \%$, selanjutnya pada perlakuan C (Vibrio harveyi $10^{6} \mathrm{CFU} / \mathrm{mL}$ ) sebesar $77 \pm 5,77 \%$, dan pada perlakuan B (Vibrio harveyi $10^{5}$ CFU $/ \mathrm{mL}$ ) sebesar $93 \pm 5,77 \%$ selama 4 hari waktu uji tantang. Kepadatan bakteri Vibrio harveyi yang 
masih mampu ditoleransi oleh pasca larva Udang Vaname hasil pemuliaan BPIUUK Karangasem adalah $10^{5} \mathrm{CFU} / \mathrm{mL}$.

\section{Daftar Pustaka}

[PERMEN-KP] Peraturan Menteri Kelautan dan Perikanan No. 75. 2016. Tentang Pedoman Umum Pembesaran Udang Windu (Penaeus monodon) dan Udang Vaname (Litopenaeus vannamei). Jakarta.

Bakhtiar. (2004). Efektifitas Penggunaan Antibiotik untuk Mengontrol Penyakit Bakteri Vibrio harveyi pada Pasca Larva Udang Windu Penaeus monodon Fabricius. Tesis. Makassar, Indonesia: Program Pascasarjana, Universitas Hasanuddin.

Bibiana, W. L. 1994. Analisis mikroba di laboratorium. Jakarta, Indonesia: PT Raja Grafindo Persada.

Brunt, J., \& Austin, B. 2005. Use Of A Probiotic To Control Lactococcosis And Streptococcosis In Rainbow Trout Oncorhynchus Mykiss (Walbaum). Journal of Fish Diseases, 28, 693-701.

Chau, N. T. T., Hieu, N. X., Thuan, L. T. N., Matsumoto, M., \& Miyajima, I. (2011). Identifcation and Characterization of Actinomyces Antagonistic to Pathogenic Vibrio Spp. Isolated From Shrimp Culture Pond Sediments in Thua Thien Hue-Vietnam. J. Fac. Agr. Kyushu Univ., 56(1), 15-22.

Donnenberg MS. (2000). Pathogenic strategies of enteric bacteria. Nature, 406, 768-774.

Effendi, R. (1997). Biologi Perikanan. Yogyakarta, Indonesia: Yayasan Pustaka Nusatama.

Feliatra, N, F., Sazali, T., \& Yuslina, S. (2011). Molecular Characteristics of Vibrio sp Causing Giant Tiger Prawn (Penaeus monodon) Disease By DNA 16s Sequencing. Agricultural Technology, 7(3), 679-694.

Feliatra, Z., \& Dessy, Y. (2014). Pathogenitas Bakteri Vibrio sp Terhadap Udang Windu (Penaeus monodon). Jurnal Sungkai, 2(1), 23-36.

Hadioetomo, R. S. (1993). Mikrobiologi Dasar Dalam Praktek: Teknik Dan Prosedur Dasar Laboratorium. Gramedia Pustaka Utama. Jakarta.

Hoa., T. T., Hoang, D. T., \& Phuong, N. T. (2006). Study on Disease In Giant Freshwater Prawns
(Macrobrachium rosenbergii). Thesis. Vietnam: Departement of Fisheries Biology, College of Aquaculture and Fisheries, Can Tho University.

Holt, J. G \& Krieg, N.R. (1984). Bergeys's Manual of Sistemic Bacteriolgy, USA: The Williams and Wilkins Co. Baltimore.

Lavilla-Pitotogo, C. R., Albright, L. J., Paner, M. G., \& Sunaz, N. A. (1990). Studies on the Source of Luminescent Vibrio harveyi in Penaeus monodon Hatcheries. [Online](https://repository.seafdec.org.ph/handle/1086 2/354), (Diakses pada 9 Januari 2019).

Mariyono, Wahyudi, A., \& Sutomo. (2006). Teknik Penanggulangan Penyakit Udang Menyala Melalui Pengendalian Populasi Bakteri di Laboratorium. Buletin Teknik Pertanian, 7(1), 25-27.

Nakayama, T., Suda, S., Kawachi, M., \&Inouye, I. (2007). Phylogeny and ultrastructure of Nephroselmis and Pseudoscourfieldia (Chlorophyta), including the description of Nephroselmis anterostigmatica sp. Nov., and a proposal for the Nephroselmidales ord. nov. Phycologia, 46, 680-697.

Nur, A. (2011). Manajemen Pemeliharaan Udang Vannamei. Jepara, Indonesia: Balai Besar Pengembangan Budidaya Air Payau Jepara, Direktorat Jenderal Perikanan Budidaya. Balai Besar Pengembangan Budidaya Air Payau Jepara.

Pelczar, M. J., \& Chan, E. C. S., (2002). Dasar-dasar Mikrobiologi Jilid ke-1. Jakarta, Indonesia: UI-Press.

Prabowo, S. A. (2003). Asian Aquaculture Magazine. Buletin Biru Laut, Edisi I Maret 2003. Lampung, Indonesia: Unit Data \& Informasi Departemen Laboratorium \& Monitoring Research and Development PT. Biru Laut Khatulistiwa.

Praditia, F. P. (2009). Pengaruh Pemberian Bakteri Probiotik Melalui Pakan Terhadap Pertumbuhan dan Kelangsungan Hidup Udang Windu Penaeus monodon. Skripsi. Bogor, Indonesia: Departemen Budidaya Perairan, Fakultas Perikanan dan Ilmu Kelautan, Institut Pertanian Bogor.

Sugama, K., Novita, H., \& Koesharyani, I. (2006). Production Performance, Diseases, SPF-Breeding and Risk Issues Concerning White Shrimp, Penaeus vannamei, Introduction Into Indonesia. Indonesian Aquaculture Journal, 1(1), 2006. 